before there was any danger that natural labour conld come on. When we consiler what difficulties there are in the way of getting together the consultants and assistants of our choice, as well as the needful apparatus in an emergency, it will easily be seen that by so doing we give the patient important adrantages. It was my request to each of the physicians who were to be present that care be taken to aroid seeing any case of contagious diseasc on the day of the operation or the day previous. I believe the request was strictly complied with by all, except one gentlcman, Dr. J. G. Ricliardson, remained away on account of the necessity he was under of risiting a ease of contagious disease on that morning. Had I been ohliged to summon them hastily there would have been no opportunity of observing these precautions. The existence of a well-defined neck of the uterus undoubtedly aided greatly in the application of the écrasenr and ligature, thus matcrially shortening the operation. Not the least of the adrantages by which the patient aud myself were favoured was the presence of the eminent gynecologists who cordially assisted me in the operation.

Dis. Smith and Goodell extended to me erery aid in their power. The former cxamined the patient with me a few days before the operation, fully approved of what I proposed to do, and saw her, in consultation with me, frequently during her conralescence. To Dr. Harris I am indebted for full access to his very valuable collection of the literature of the subject, which he cordially placed at my disposal. Through the kindness of Dr. Broomall I was enabled to obtain from the Woman's IIospital a skilful and intelligent surgical nurse. But when all did more than $I$ asked of them, it would be invidious to distinguish. I have never seen more united action at a consultation, nor lave $I$ ever witnessed a more enthusiastic determination on the part of cach to do all in his or her power to promote success, and to the nuited efforts of all is largely due the honour which belongs to the first successful Porro operation in America.

\title{
Anticle: III.
}

Gastric Remittext Fever of Infants and Toung Persons-A Distinct

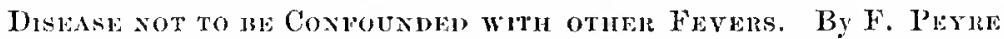
Poncunn, M.D., l'rof. of Mitteria Mediea and Therapenties in the Medical College of the State of Soutl Carolina, Charleston; Ex-Vice-President of the American Medical Association.

WE meet from time to time witl cases of remittent ferer of greater or less severity in clildren and young persons, which are not typhoid or inalarial; and as we can get no, or scarcely any, recognition of it from those around us, we propose to examine the question of its existence and true status. No practitioner should be indifferent to such a subject-for errors 
in diagnosis may lead to fatal results. The cases vary in gravity; but of eighty or more examples - treated by us during many years outside of hospitals, and concerning which we lad not the slightest doubt-_all lave recovered.

In a prize essay ("Illustrations of Disease with the Microscope"), pulblished by the State Medical Association as far back as 1861, we took occasion to give a brief sketeh of "Gastric Remittent Fever," and to assert, for reasons based upon our own experience, that it had a distinct elaim to be considered and treated as a scparate disease; that it was not a variety, but a true species-as much so as yellow, typloid, malarial remittent, intermittent, rlieumatie fercr, or any other classic malady which has been isolated, and marked down as such in nosological tables.

It is singular to observe low all this is iguored, as it scems to be, by the profession gencrally, and by some of the text-books in particular. We lave not searehed them all, but Dr. Geo. B. Wood is one among the comparatively recent writer's who, as far as we know, does give a pretty fair and full aecount of this affection, and in a measure separates it fiom otler disenses. Very few recent writers place it as a distinct disensc under this title in their indexes, or give a separate chapter to its consideration and treatment. Nor do we find it accurately and fully described in their works. The medical journals, as far as we know, seldom or never refer to it.

It is very often, we think, dependent upon, or assoeiatel with the presence of worns in the intestinal canal, and many writers, we admit, treat of "Worm Fever;" but we assert most distinctly that gastric renittent fever las often no dependence npon, or relation whatever to parasites in the intestinal canal; that it is a distinct, separate, isolated affection-and not by any means very rare; that it is of the highest importanee to reeognize it carly; that it requires a treatment peculiar to itself alonc; and that it is scarcely ever fatal, if recognized and properly managed at its inception. There need be no fatality about it, as there are no lesions whieh lead to such a result; there being only an irritation of the gastro-duodenal, or gastro-enteric nucous membrane, and no truc inflammation, we think, nor any serious organic altcration of the glands, or other inportant vital organs-as soon as the irritation is removed the fever ceases! We do not pretend, as a medical Stanley, to have made all these discoveries alone; we only unfurl our flag over lands partially abandoned, after liaving bcen once occupied and marked out; for the disease has its listory: was long since recognized, known, and described with more or less accuracy and completeness. Our claim is, that as soon as we saw a few cases and examined their essential features, we noticed its dissimilarity to other forms of remittent fever, and it became clear to us that it was as much an entity as any other disease. Among some comparatively recent authors the disease is divided up among, or merged in typhoid, malarial remittent, typho- 
malarial, ephemeral, and worm fevers-all whieh we regard as essentially crroneons. 'To confound it with these only as respects treatment, is to run the risk of inıparting a fatality to it which it need not exhibit.

As for the great majority of the professional brethren in this State, or in our immediate vicinity, they secm to pay little heed, so far as we can learn, to the existenee of any such affection; and yet they must necrssarily see and treat it under some other name. But a brief while since we heard it stated that no sueh disease existed-that the eases of it were only cases of aborted typhoid! Our repented efforts before the "Medical Society" to seeure attention to the subjeet, and a due recognition of the distinctions we assert to exist in the features of the disease, have failed. We seldom or never hear it reported by membors, or recorded in the weekly bills of mortality of this city, or of Now York-which we bave reeeived for years past.

We shall not undertake to give its bibliography, to enter upon any full or eritical inquiry as regards priority of deseription, and the relative contributions made by the seveml writers who have described the disease; or to eite eacls of the author's on fevers or on the diseases of children who have either ineidentally, or more or less fully, reeognized gastrie remittent ferer as a distinet and separate affeetion. But we slsall certainly, in our effort to bring about a better understauding of the disease, point out any important diserepaneies, or omissions, in its history by the several authors who have referred to it. Our readers must now give us their patient attention whilst we examine opinions by writers of reputation and authority-for they are sometimes dangerous.

Dr. W. Butter, in his "Treatise on Infintile Remittent Fevers," 8ro. London, 1782 (see Copland's "Dietionary, Art. Fevers"), seems to have been one of the earliest writers who gave a distinetive sketel of this affection-recognizing and describing its most salient characteristies.

Dr. Charles Lee, the Ameriean editor of Copland, though he has given an exeellent summing up of the varieties of fever (p. 1120), is often far wide of the mark when he speaks of the excessive danger and fatality of "Remittent Fever"-whilst alpearing to allude to this form of fever; but eonfounding it with malarial remittents-with which it has very slight, if any connection. Dr. Lee says :-

"There is no discise of more frequent occurrenee in our comtry then the remittent fever of children, as with the exception of eroup, pnemononial, and in the hot sersons of our large cities, cholem infantum, there certanly is none more precarious in its progress, less amenible to treatment, or more fittil in its consequences."

We are glad to note that Prof. S. H. Dickson ("Essays on Pathology and Thernyeutics," 1845, elap. "Infintile Remittent"), says of it, "it" well managed recoveries are the rule." In faet, we have no form of remittent fever among children at the South to whieh Dr. Lee's description, or sinister forebodings would apply. They would hardly be applicable 
eren to malarial remittents. Several other writers refer to the mortality of the disease in terms whieh we will show by the testinony of others and ourselves to be very questionable. Some of these author's declare that it sometimes commences witl diarrloea. We have never seen one out of numerous cases begin witl any condition save that of costiveness. This, in our experience, ushers in all fevers_-glandular and secretory action being arrested at their inccption-prineipally, we suppose, from the influence of the incrensed temperature (fever) upon the blood and the nerves which control the functions of the glands. Neither Wood nor Copland refer to the "red tongue," which we consider as one of the essential and characteristic marks of the disease. Prof. Diekson snys that the tongue is at first furred and loaded, and afterwards "fiery red ;" strictly the tongue is nevor loaded-there is only a white fur over the centre-but in the last observation he is accurately correct, so far as the point and edges of the organ are eoncerned. He does not allude to the inutility of quinia in the treatment, nor to the great effieney and power of alkalies, such as soda.

Dr. Layeock devotes a chapter to the disease under the title-which we eonsiler to be the only trne and correct one-of "Infantile Gastrie Remittent Fevers;"-so we are sustained by, and do not hesitate to coneur with these earlier writers who regard it as a distinct form of fever, requiring a special method of treatment; and that it should not be eonsidered a "gastric entarrh!"

Some of the authorities do aetually regard the disease as aborted or mild typhoid fever, than which nothing, we feel snre, is more erroneous, or shows a greater absence of perception of its true nature. Gastric remittent fever does not present the fucies of typhoid fever at any period of its carcer. Its physiognomy is essentially distinct. The tongue may beeone dry (though we have never seen it so) at the eonelusion of protracted cases, but the temperature variation is not nearly so uniform as in typhoid fever. The evanescent delirium and wandering during or upon waking after sleep, sometimes aeeompanied with hallueinations, of gastric remittent-which also occurs early in the disease, and is the resnlt of too much heated blood in the brain-is a very different thing from this symptom, as it is met with only in the later periods of typhoid fever. In the latter, delirinm and coma and dry tongne, with sordes, occur late; and are cansed by poisoned blood acting on the nerres, and the brain-thus depressing the nervons centres, and diminishing the activity of the excretory glands. In gastrie remittent fever the intelligence is good, save during the temporary and fugitive deliniom; the eyes are clear, and perspiration oceurs only at the crisis just preecding eonvalescence. The tongue is always and necessarily red and pointed-what we call the snake's tongue-though white in the centre, it is never foul or loaded. Most of the autlorities we have referred to, and otliers consulted, admit that worms are not the sole eause of the disease; one or two assert (erroneously we

No. CLXI._-JAN. 1881. 
think) that they never arc. Dickson says they certainly are not the invariable canse. Our estecmed and indefatigable friend, the late Dr. Condie, can scarcely be referring to so benign and easily managed a discase as gastric remittent fever, when he states ("Diseases of Children"): "In every instance it is either a gastro-enteritis, an ileitis, or an entcroeolcitis accompanicd with febrile reaction;" and he remarks that the lesions discovered after death "are chiefly infammation, more or less extended, of the digestive mucous membrane, in some instanees of the stomach and upper portion of the small intestines; in most instances of the ileum and colon." He even speaks also of peritoneal inflammation as a complication, and he advises leecling, etc. The disease we ale describing is not eoncerned in any of its stages with this membrane; in it we have never even seen enlargement of the mesenterie glands.

Copland only, whilst referring to "Complicated Remittent," speaks of "inflammatory states of mueous membrane," and "a foul, loaded tongue with red sides and apex." We would hesitate to deseribe gastrie remittent fever, as we meet it, as an inflammation. It is seareely more than a gastro-duodenal irritution-with sufficient intensity only to eause fever, being the result of depraved digestion. But it is difficult to declare when an irritation merges into an inflammation-this being often a question of plus and minus. The irritation, whatever be its nature, eertainly is suffieient to cause fever. Evanson lad noticed that any exciting cause of irritation, "as swallowing a marble, will give rise to a remitting type with evening exacerbations."

Niemeyer includes in one elapter "Gastric fever, Catarrlal, and Bile fever" under affeetions of the "Intestinal eanal"-having before treated of "Aeute gastrie eatarrh" in his section on "Disenses of the Stomach." In his Catarrhal fever there is immense exeretion and diseharge of mucus -the tongue being first eoated and furred, afterwards glazed and fiery red. Wo have never seen this discase; and we never eould eomprehend why the Germans, and their followers in this country, call so many of their cases of intestinal irritation "catarrl!" In our gastric rcmittent fever the skin is dry, the system is parched by ferer, and there is no secretion of mucus as a distinctive fact from the stomaeh or intestines; none is either vomited or passed downwarl in any material amount. Tre think it advisablc to quote what this able writcr says of "Gastric Fever," which approaches nearcst to the diseasc that we are considering. We cannot agree with regard to the exceeding pain about the joints and limbs, which with us is only found in influenzas, grippc, dengue, etc.; and he fails to notice the red and pointed tongue-which we assert to be obriously an essential claracteristic of gastric remittent fevcr. With these cxceptions, one cannot too highly commend the following:-

"Many physicians, particnlarly among the Germans, describe as gastric ferer a disease running an acute course, in which high ferer is only accompanied by lyspeptic symptoms, and generally by diarrhoen, while there are usually no symp- 
toms that would indicate severe disease of any important organ. Celelmated authorities, particularly those clinical observers who have developer in hospital, and have had only hospital practice, consider all eases of so-called gastric fever as milal cases of typhus. I camot at all agree with this view. Every physieim in private practice often has the opportumity of secing, after errors of cliet, without any suspicion of infection, symptoms of variable dunation, which exactly answer" to those of rastric ficrer. "If this be so, even where we cam find no error of cliet, wc must be earefil alont inferring that there is an infection, and must acknowledge the possibility that eatching eold, atmospheric and tclluric influences, and other sources of iujury, may excite a similar set of symptoms. Bnt I will not attempt to deny that numerois slight eases of typhus arc diagnosticated as gastric fever.

"As a rule, gastrie fever begins with several slight chills, rarely with one severo one. 'The pulse quickly rises to $100 \mathrm{or}$ more. According to the few observations that have been mate, the temperature is sometimes normal, in other cases it is decidally increased; it may reach from $162^{\circ}$ to $105^{\circ}$. 'The constitutional disturbanee is very matked. The faintness is so great tlat the patient remains in bed; the limbs, partienlarly at the joints, pain 'as if they would burst.' The insupportable healiche is usually increased by laving the lieal on a feather pillow, while it is occasionally relieved by binding a towelfirmly around the head. The patient dues not sleep at all, or is distubed by dreans. The symptoms of disease of the stomach or intestines vary. Usually the appetite is lost, the tongne coated, the taste slimy or bitter, the breath is bad, the patient complains of a feeling of pressure and fuhness in the epigastrium, and is seusitive to pressure there. 'There is also eructition of gases and lluids, usmally acid produets of abnormal gastrie digestiou. Oreasioually there is repented vounting. At first there is usually constipation; lut latel, paiticularly when the disease is protracted, there is diariluci, preeded by more or less colicky pain; the stools are fluid, and colonred green by bile, and are sometimes mucons.

"Oeensionally these symptoms pass off quickly, aucl the patient, who is one day in a sal plight, feels quite well the uext (cplemera). At the same tine herpetie vesiches not unferenently come on the lips. Wre shoukl uot consider this a distinct disease, a febris herpetien. Her ju' labialis accompanies gastric fever as of ton ol perhaps of tener than it loes punemonic ol intermittent fever, and las the sume significance in the former flisease as in the latter. But the disense does not by any means always terminate in one day; it often continues several day's, but raely lourer than a week. In persons who do not bear well the fererish increase of temperature, or the ronsumption eaused by the increased development of lieat (we have frequently said that individual pualiarities vary greatly in regard to this), there is great (lepression, the mind is atlocted; instead of lleans, the patient has delinimi and, if at the same time the tongue becomes dry, the similarity with typlus is rery great. It often happens that the true nature of the ease is only explained at the sixth or eighth day, by the sulden inuprovement and the rapil convalescence."

And here our author takes occasion to warn the plysician against being in error" in the diagnosis, as he says "even the laity no longer believe that under certain circumstances 'gastric fever' may become ' gastrie nerrous' and this arain develop into 'nervous fever.' They know that these two diseases are of different nature from the first." He tells you low they may be distinguished.

Niemeyer salys: "Muriatic acid has a great reputation in the treatment of gastric ferer" ( $\bar{s} s$ to $\tilde{\tilde{\delta}} \mathrm{vi}$ of mucilage), furnishing "the gastrie juice with the acid to which, as pliysiology shows, it owes its digestive powers." We have never used acids in our gastric remittent fever-thongh we have found acids, with gentian, to act brilliantly in certain forms of dyspepsia attended with eructation, which, on that aecount, are very depressing. "In 
catarrhal fever we prescribe," says Niemeyer, "the alkaline carlonatcs, particularly the tinct. rhei aquosa"-in large doses, as advised by Schonlein"and can fully support its reeommendation as almost a specific in this diseasc." He elsewhere says: "This evidently depends upon the well-known power of the earbonates of the alkalies to diminish the tenaty of the mucus and render it more flnil." As we said boforc therc is no muens in gastrie remittcnt fever. We can certainly spcak in as higl terms of nitre as a diaphoretie, united with sola as a eorreetive, in our form of fercr.

Dr. Flint, in his "Practice" (4th ed., Phila, 1873), describes the diseasc under consideration, as well as we can discover, nnder the head of "Subacute Gastritis," and he only refers ineidentally to gastric catarrhs; nor is the line drawn very strongly bctwcen the two aflections, as is done by Niemeyer. Though this distinguished observer advises rermifuges where worms are supposed to be present, he lays no stress "pon the verminous origin of fevers in childlen. In this we think he is mistakenmany cases of gastric remittent fever in children we lave traced to the irritation caused in part at least by the presence of worms, as well as by any other irritant. We are glad to find that Flint sustains the opinion that it (subacute gastritis) is very seldom fatal.

Dr. Geo. B. Wood, in his "Article 1st, Irritative Fever," says :-

"The Infonti7e Remitlent Fever of authors, so far as it is a distinet affection. is an example of simple irritative tever. Inder that name, however, have been described several different diseases, resembling eneh other only in their febrile and remittent character, and in the circumstance of oceurring in ehildren. Gastritis, enteritis, mesenteric adenitis, hepatitis, tuberenlan diseise of the lungs and bowels, and especially enteric or ty phoid ferer, have been confounded uniler the vague title of infuntile remittent ferer." . . . " "Yut there can be no doubt, I think, that a remittent irritative fever, corresponding with the definition given, at the hear of this article, does frequently occur in young children. Unless in conseruenee of the supervention of intlanmation, which plates the discase among the plikgmasix, it almost always ends in recovery."

Only a misconception of the nature of the disease, and the abuse of purgatives, conld induce this conversion, we belicve. He regards it as "identical with worm fercr," and distinct from enterie fever. ("Practice of Medicine," vol. i. 220.)

That we are correct in our opinion of the importance of a critical inquiry, inasmucl as the profession seems to be at sen on the subject, we necd only quote also the opening paragraph from Dr. J. Lewis Smith's chaptcr on "Remittcnt Fever" in his "Diseases of Infancy and Chillhood," Phila., 1876.

"If a plysician were to consult the standard treatises on disenses of elildren, in order to aseertain the natme of remittents he would rise firm the porrasl with no elear ideat of it. One tells us that the remittent ferer of ehildren is identical with typhoiel fever of adules; anolher, that it is a gastro-intestinal inllammition ; and finally, Inillier believes that there is properly no such disease, and that the term shonld be dropped from the nosology of dhildren. There is, however, a remittent ferer of ehiklren as well as adults, and mueh of the confinsion which exists in reference to it arises from the fact that writers have not kept in view what constitutes a fever. Fabrile artion which has a loeal eause is not an essential ferer, and should not be described as such."” 
Smith does not devote fiftcen lines to the treatment, nor threc pages to the wholc subject. "If we have aseertaincd by a carcful examination that the fever is remittent, and not symptomatic but essential, there is one remedy which is required in nearly all eascs, namely, quinia, or its equivalent, cinchonia." Quinia is nseless in true gastric remittent fever! As we have shown by its actual test in five obstinate examples, and by curing without its nse every other case.

So able and gencrally sutisfactory a writer as Jno. Syer Bristowe ("Practice of Medicine," I"hila., 1876) gives a very brief, and we must say a most inadequate, sketch of "remittent fever," and makes no allusion whatever to the infantile form of it. He says that intermittents and remittents are convertible the one into the other as accident determines, and that there are no distinct lincs of denareation between them. Gastric remittents never become intermittents! As they depend upon a local irritation for their cause, and not upon malaria, their symptoms cannot iutermit. Their remittent character is preserved $u$ p to recorery.

We desire to be concise in the sketel of the disease as seen by us. We entitle it "Gastric Remittent," because the stomach itself (and perlapps the duodenum, for it is difficult to fix precise limits), and not the intestincs, as in a true enteric ferer, like typhoid, is the sent of the disease; and, not to refine too much, it is not necessarily "infantile" in the strict sense of the tcrm. There are always daily remissions, which have not the regularity that is found in typhoid fever. The absence of the gravity, the distress, and other symptoms belonging to the latter, which it is needless to mention, strike the beholder at the first view of a typical casc of gastric remittent fever.

Sketch of the Disease.-A child, or young person, living in the city of Charleston, for example, if breathing marsh malaria at all, very rarely reccives it in so concentrated a state as to snffer by this causc alone from intermittent, from congestive, or even from what may be styled an attack of hilious remittent fever. But slould the same child be subjeeted to a repeated or long-continued course of inproper nourislument, including all things that arc hurtfil_cakes, confections, unripe fruit, etc.-after a time nutrition becomes impaired or arrested; the ncessary digcstive juices being imperfectly claboratcd from the irritated and depraved condition of the mucous and glandular structures, effete matters accumulate in the systcm each day more and more; the wheels of life are finally clogged, the play of affinities between the organs are disturbed or arrested, and fever is declared. The sourec of this fever is local, and its cause, irritation, of course. Every thing has been slowly conspiring to this end, but it rcquires sometimes the addition of a cold, perhaps, or other disturbing cause, to develop the fever, which is not an intermittent, but a gastric (or gastroduodenal) remittent. It is always a remittent, gcnerally lcssening 
during the early morning, to be inereased at night, until it slowly disappears after one or more week's duration, when the loeal effects of the irritants are removed. Sometimes, though rarely, the fever is very lighl, but it varies in intensity in proportion to the sum of the eauses which produec it, and the strength of the constitution; by which term we mean the general endowment which the organs of the individual possess for performing their lealthy, normal funetions-and consequently for regaining those functions when impaired by exeesses. Even when a cold, or other accilental additional eanse, does not listen the development of the fever, it is produced suddenly-d'emblee, as the French call it-seemingly by an effort of nature to reetify the abnormal condition, gradually indnced by the depraved state of the nutritive organs, which has reaehed, as it were, its elimax. But this fever is much more than a mere gastric embarrassment, if it is not a direct result of gastrie, or gastro-enterie irritation, or inflammation. We ineline to the belief that it is nothing more than an irritation-but drastic purgatives might intensify and prolong the mischief, and convert this into an inflummation. Copland afin'ms that it is decidedly not an inflammation. At any rate the fever indicates the general disturbanee-the commotion of nature, as it werc-aeconpanying the efforts of the system to throw out the morbid products gencrated. 'The remedial measures, which will be given in detail afterwards, tend logieally, we may say, to aid in restoring the imprudent_oftentimes innocent-sufferer to his pristine eondition.

When one, whether child or adult, with these gastrie or gastro-enterie complications removes to, or resides in a maliarial region, he is liable to suffer fiom the usual resnlt of malaria-which, when it affects any system with healthy organs, produces only intermittent fever, or chill and ferer. But under the conditions just specified the attack must neeessarily be superimposed upon the gastric or gastro-enteric derangement-whether this be irritation or inflammation ; and the resulting fuver, when this complication exists, in our opinion, will invariably be a remitting fever ; and the treatment, to be safe and quick, must be directerl to both conditions or elenents in the disease which results. In other words alteratives, revulsives, antipyreties, eoll applications, must precede or accompany the use of quinia or other mere antiperiodic; for we have in both eases an irritated or eongested condition of the gastro-duodenth nucous membrane pli's the malarial poison.

Gastrie remittent ferers, be it observed then, are not confined to eities; but they may occur just as firequently (thongh probably under a graver type by reason of the greater anount of malaria in the eountry), in situations where fevers of paludal origin are rife, and where mularia is generally, but often erroneonsly, thought to be the sole carse of all the remittent fevers which manifest themselves_thus often leading to great errors, or 
important omissions in treatment. We shudder to think how many cases of uncomplicated gastric remittents have been unrecognized and mistaken for malarial fevers. Uncomplieated gastric remittents can also be met with on the lighest mountain plateaus, where not a whiff of malaria exists. If this be truc, surely then malaria need not always cnter as an element in the problem of treatment.

We say, therefore, that a fever witlı a gastric or a gastro-cnteric complication is always a remittent or, possibly, a continued fever, because we believe that the constant presence of the gastro-intestinal irritation, maintains and keeps up the continucd circulatory excitement and pyrexia (fever, in other words) - the malaria being respousible only for the periodicity.

Often, were it not for the gastric irritation, or the wcak organ, the fatigue, the exposure to a sudden cliange of tenıperature, the individual would eseape even though exposed to the malaria-and thus many do escape. At any rate there are two important clements refered to above, either or both of which may be present, and which have to be considered in the treatment.

We may refer in passing to a third form, namely to bilious remittent ferer-using it as a distinct term-because we believe that remittent fevers occurring in malarial regions are often accompanied in dissipated persons, or those of bilions temperament, by marked disturbance, congestions, etc., of the biliary organs-the liver being implicated, in addition to the gastroduodenal tract, mucl oftener than either in intermittents or in the gastric remittents which we were describing. We never hear of a bilious intermittent! But intermittents, agues, chill and ferer lead to cluronic enlargement of the liver, spleen, and mesenteric glands, followed by anæmia, leucocythemia, and other blood degeucratious-which are natural results of the congestions occurring in these blood-naking organs during the cold stagc. These results never occur in gastric remittent fever.

Now gastrie remittent fercrs, as we have said, are a not uncommon form of disease, particularly among children in the city of Charleston. They are characterized by a not very high thermometric rangc $-100^{\circ}$ to $103^{\circ}$ - by a slight tenderness upon pressure over the stomach and duodenum, by a mild and eranescent delirium specially upon waking, cven during the day; by the absence of the chatrieteristic look of typhoid fever -that of lowness, depression, and exhaustion-and by a tongue pointed and red at the point and margin, with a white fur in the centre. The tongue is seldom if ever what is called fonl, or loaded, as in bilions, and sometimes in intermittent fevers; nor has it a yellow fur as in disorders where the liver is particularly involved. We do not regard the recognition of the exantliem of typhoid as essential to its diagnosis-but we certainly will not find it in gastrie remittent ferer. We have never met with herpes labialis in any of our cases. 
Treatment.-It follows naturally that gastrie remittent ferer can be brouglit to a successful termination: never by quinia alone, as in pure intermittents, but by mild mercurial alteratives (a lialf to three or four grains of calomel, two to four of magnesia and rlubarls each, to which the same cuantity of soda is added-oecasionally used at the beginning of the disease merely to act as a corrective and laxative-one powder being often sufficient; a few grains of Dover's powder may be given at night occasionally, or after the above alterative laxative powder lias acted. The following combination has, in our experience, been suffieient in all cases to reduce and abolish the pyrexia :-

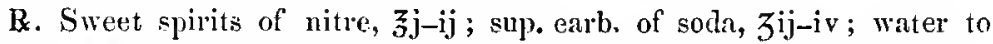
亏viii.-M. S. A tablespoonful every two to four hours, as long as the fever exists. Lime-water, or other similar agents, may be given repeatedly. Revulsives of mustard should be applied to the abdomen at lenst twiee a day, and mustard foot-baths ordered at night, so as to assist in removing the gastric irritation - with cold sponging to the head and arms freely and eontinnously employed for ten to fifteen nimutes at a time, whenever the fever rises. These measmes combined reduee temperature, eorrect the gastrie derangement and prevent delirium. Quinia may be employed afterwards, if at all, only as a tonie. Sueh a course of treatment it may be saf'ely asserted scarcely ever fails-never in our experience.

The nitre in the above preseription reduees the fever, and the sola correets the disordered condition of the gastro-duodenal mucous membrane. We sometimes add one or two draehns of camphorated tincture of opium to this mixture, and, if the fever is high, one or two drops of tineture of aeonite to each dose.

The following passage we translate from M. Mialhe (Chimie Appliquée a la Physiologie et a la Thérapentique, Paris, 1856) to show that it is not easy to exaggerate the effects of soda-regarded by euperfieial observers as a correetive of aeidity only.

"Alkaline agents (of which the preference is not important, potash being enite as good as sodk) give rise to and disengage ammonit in the system. . . . The alkalies by renson of their importanee in the natural phenomentil of decomposition, of absorption, of oxidation of sugar and starchy substanees, of fitty miltters, oils, and resinous substances, are at the leat of the most useful and much used neelicines. They maintain the blood in its necessary degree of viseosity, fluidity its too great coagulability, inerease cirenlation, dissolve the principal elements (albumen and filrine), which eonstitute the bases of nearly all engorgements. They liquefy the elements of the bile, prevent them from beeoming thick, from concreting together, from forming calculns. They reanimate and regulate intestinal digrstion; facilitate the secretions; satnmate the acids, which, taking their origin within the economy, can, through their exeess, occasion disentse: such is gout, rheumatism, diabetes, or those insoluble collections constituting chalky coneretions, urinary calculi, deposits, ete."

Copland recommends sulphate of potash and rlubarb as a mild laxative in gastric fever; and we have seen our friend and former colleague, 
Dr. D. J. Cain, now of Asheville, N. C., employ it successfully, used at the inception of the attack.'

Let us relate briefly two cases for the instructive contrasts they afford:-

CAsE I.-A lady in goor health, residing in a pine-land summer resort, of doubtful reputation as regards health, after undergoing much anxiety, much fatigne, and exposure to night air, fell ill of fever with repreated chills, and refusing to take quinia died in twelve days of algid fever. Thougl not managing her casc, sle was all the while immediately under our eyes.

C.ssv II.-Her daughter, aged 8 ycars, also a liealthy girl, was taken sick a fortnight after. During the illness of the mother and previonsly, a eareless nurse hat given her everything that was hurtful to her digestive organs - she had also bcen exposed to cold, etc. Living in the same house with these cases, and the last falling unler our care, we did not lesitate to pronounce it one of imeomplieated gastric remittent fever. She harl ferer for a fortuight with daily remissions, and she hat the treatment indicated above: A few grains of calomel and lunbarb at the berinning, the febrifige mixture of soda and nitre, a few grains of Dover's powder at night, cold sponging to the lead, hands, and arms, mustard plasters to the pit of the stomach, with hot pediluria at night. 'Though she seemed quite ill, she recovered pertectly without taking a single girain of quinia-notwithstanding the history of her mother's case fresh in our recollection-and with its warning against the danger of omitting the use of antiperiodics. It required all our comage to negleet this warning-in the fice, too, of the outside elamor."

1 The following was reecived from Dr. S. Barueh, of Camden, S, C., in reply to a letter:-

"The disease you allude to as mastric romittent is one that I have peeognized and treated long ago. It oceurs chicily in children, but not exclusively. It is alstinetly remittent, but does not yieid to quinja until the primse vire are thoroumlily lestored. There is exeessive proliferation of elpithelium, with secretion of-or latlere f'ormation of mueus, giving rise to what the ciermans eall gastric catarlh. The treatment I follow is a dose of calomel and rluthrb to clemse and prepare the way; then aconite and nitre, sponginir, and other expectant anti-febrifuges. I order a dose of quinin enrly in the morning, but I find that it does not prevent the accession of fiver, until the nucous membrunes are relieved of the tnucus and their epithelinm. Inse quinta in repeated doses, feeling my way until the effect is pronounced. The difference between this tever and malnitial remittent is pronounced in the efheacy and inumediate antidotal eflect of quinia in the latter, and the difficulty of eff'eting a prevention of the exacerbation in the former. In the one (malirial) it ats as an antidote and specific against malarial infertion-in the other its influence is upon the nervous system, preventing a return, just as it does iu intermittent menral wia (not malarial). It apluronches a low fever, presenting typhoid symptoins, but the bowels are not easily moved. It is an olstinate affection, yielding only after eonsiderable metication. T believe it has sonne tendency to self-sine, but this can be aided materially by treatment. Such is a brief and imperfect view of gastrie remittent as I lave secn it."

3 We may be pardoned for relating the following as a war record: We attended a young gentleman in Virginia who was believed to be desperately ill by all who were arould hion; as he hat a persistent, high fever for many days, and even in daylight, when awake, was delirious-seeing objects snch as is common to those with delirium tremens. We lave scen this symptom three times in cases of gastric remittent fever. We assured his friends that it was a case of gastric remittent fever, and that notwithstanding sinister appearances, le would surely recover. This prediction being verified, the grateful mother gave us a hat which cost in Rielimond \$950-in Confederate money! 
The frequent and prolonged use of ealomel and opium, or of purgatives, for days-which are, or were supposed by some, essential to the relief of gastro-intestinal inflammation, as well as to the management of the socalled bilious or eountry fever,- - or an exelusive reliance on quinia, are uncalled for, if not decidedly injurious in cases of gastric remittent fever.

In bilious remittent fevers of great violence, dependent upon great intensity of the malarial poison, and where there is evident torpor, or eongestion, or chronic disease of the liver, ealomel and quinia, with other appropriate means, may be used before the paroxysms often with grcat advantige. But mercury, ealomel and opium, or drastic cathartics, need not be given every four or five liours for days-as was once, may be is now, the practice with some-for their supposed curative powers in any ferer, save the guarded use of calomel and opium as an alterative absorbent in inflammations of the fibrous or serous tissues, pleuritis, peritonitis, iritis, etc. Some believe that the opium alone is sufficient. Thus given it irritates and heeps up the gastro-enteric irritation, or infammation, and with it the fever and general excitement of the system. We have treated ninety eases of malarial fever in the Marine Hospital, Charleston, many of them of great severity, with but one death-where only a single initiatory dose of calomel was given occasionally. Sulphate of cinchonia was used to test its rirtues as an antiperiodic. (See report in Charleston Medical .Joumal and Review, rol. xiii., 1858, and "Prizo Essay," p. 69.)

Agues, pure intermittents, and fevers of verminous origin, are very different things. In these a single mercurial laxative, quinia, arsenic, or an appropriate vermifuge are amply sofficient, because it is of unmixed malarial origin in the one case, and the existence of a parasite in the other -lience the specific or the vermifuge is omnipotent.

These distinetions must be kept erer in mind, in order to avoid uscless or injurious medication, or the omission of that which is essential.

\section{AliticLF $1 \mathrm{~V}$.}

Amaliogis from Lesions of rue Eyebrow on Orbitai. Regron. By J. Saxtos Frinandez, M.D , of Mivala. Translated from the Spanish by

A. B. DE LuNA, M.D., of Now York.

Wocros of the superciliary region, and the loss of sight which often follows, have always been studiel with much interest, but so far no satisfactory explanation has been offered regarding the relation between the solution of continuity and ineidental amaurosis.

Previous to the discovery of the ophthalmoseope many cases had bcen reported, but they are as vague as the more recent reports in which an examination of the internal eye has been neglected. 'That the ophthal- 